\title{
Seventh-day Adventists, Human Rights and Social Work
}

Bedřich Jetelina

The present paper aims to show and illustrate the consequences of the specific theological motivation and historical legacy of the Seventh-day Adventist Church for human rights and social work. Since an important aspect of human rights is who proclaims them,' the paper not only outlines the basic Adventist points of departure but also shows what practical attitudes the Adventist church has taken in the past and what challenges it faces at present. It points out where Adventist views coincide with American conservative Protestant thought, where they deviate from it, and to what extent is this deviation due to specific Adventist points of departure.

Adventist thought is rooted in American culture of the 19th century influenced by the philosophy of the so-called Scottish realism, ${ }^{2}$ which echoed the anthropocentrically conceived religious liberty vision of John Locke. ${ }^{3}$ In this sense I therefore subscribe to the view that the Adventist emphasis on religious freedom derives from an anthropocentric, not a theistic conception of human rights. ${ }^{4}$ For that reason the facts mentioned by this text concerning the central European or South American sphere always need to be considered with the American discourse in view.

\section{Adventist eschatology as theological motivation since 19th century up to the present}

The Seventh-day Adventist Church proudly maintains that it has actively engaged in some areas of human rights protection, especially concerning religious freedom and abolition of slavery, since the time of its origin. ${ }^{5}$ But the Adventists themselves note that they had taken over many of their crucial concerns in the sphere of human rights and social commitment from the Christian Connection movement ${ }^{6}$ and that theologically they draw on the legacy of the so-

1 Cf. Jaroslav VOKOUN, Úpadek lidských práv: Devalvace? Dialektická negace? Perverze?, Křestáanská revue LXVIII 1/2001, p. 13.

2 Cf. e.g. Millar J. ERICKSON, Truth or Consequences, Downers Grove: InterVarsity Press, 2001, pp. 309-310 or William H. GOETZMANN, Beyond the Revolution: A History of American Thought from Paine to Pragmatism, New York: Basic Books, 2009, p. 54.

3 Cf. John LOCKE, Dopisy o toleranci, Brno: Atlantis, 2000.

4 The theistic conception "is characterized by deriving the idea of the dignity and rights of the human being from his special relationship to his creator God, with reference to biblical sources ... The other conception of human rights, which appeared later, is characterized by deriving these rights not from the special relationship of the human being to God, but from the dignity of the human being itself, which is ultimately independent of God. Here one can speak of the anthropocentric conception of human rights ... An example of such a right is the right to freedom of conscience. If we conceive freedom of conscience as consisting in the right to choose any religion or no religion at all, then such a right is in obvious conflict with the first commandment of the biblical Decalogue which, as it is well-known, says: You shall believe in one God. Therefore according to the older theistic tradition a right to freedom of conscience thus conceived precisely speaking does not exist." Stanislav SOUSEDÍK, Idea lidských práv a její dvě verze, Teologické texty 3/2007, p. 133.

5 "From its very inception in the middle of the nineteenth century, the Seventh-day Adventist Church has supported human rights. Inspired by biblical values, the early Adventists were involved in the struggle against slavery and injustice. They claimed the right of every person to choose beliefs according to conscience and to practice and teach his or her religion in full freedom, without discrimination, always respecting the equal rights of others. Seventh-day Adventists are convinced that in religion the exercise of force is contrary to God's principles." (C 50th Anniversary of the Universal Declaration of Human Rights - Official Statements (on-line), at http://www.adventist.org/information/ official-statements/statements/article/go/0/50th-anniversary-of-the-universal-declaration-of-human-rights/18/, retrieved January 7, 2014. 6 These were striving for full political and religious freedom, in the social sphere struggle against slavery, advocating temperance, qualified health care and equality of women. Social issues concerning just rewarding of workers etc. were not among the priorities of Christian Connection. Cf. (C) Bert HALOVIAK, Some Great Connections: Our Seventh-Day Adventist Heritage from the Christian Church - General Conference Archive, Silver Spring, unpublished document (on-line), at http://www.adventistarchives.org/docs/AST/ChrConn94.pdf, 
called Millerite movement, which in 1844 expected the end of the world through the Second Coming of Jesus Christ. When the vision was not fulfilled, the Adventists reinterpreted the Millerite calculations, whereby they evaluated the expected event of Christ's coming as an event in the heavens. ${ }^{7}$ They retained the Millerite methodology of interpreting the Bible, ${ }^{8}$ which they elaborated further, as well as the conviction of an imminent end of the world, which will culminate in Christ's Second Coming, but unlike the Millerites they did not set a precise date for the event. From the Millerite movement they also took over the so-called historicist understanding of Biblical prophecies. ${ }^{9}$ From this they derived relations between Biblical prophecies and world events they considered important or were undergoing. On this view the Book of Revelation and the prophetic parts of the Book of Daniel really represent coded history of the world since the time of writing up to the eschatological end of the world.

As a result of the historicist approach to prophecies the symbols of beasts in the Book of Revelation were interpreted as concrete historical religious-political powers. "The beast of prey with ten horns and seven heads" (Rev 13:1) was taken to be the Catholic Church. ${ }^{10}$ The beast which "had two horns like a lamb but spoke like a dragon" (Rev 13:11) was interpreted as the United States of America. ${ }^{11}$ On the Adventist interpretation the two horns "symbolized the two foundational principles of the American republic: Republicanism (or civil liberty) and Protestantism (or religious liberty). The dragon voice signified a betrayal of those principles leading to the final oppression of the faithful."12

When the Adventists subsequently concluded that like Seventh Day Baptists they should observe Saturday as the day of rest, they justified this conclusion by reference to the eternal validity of the Decalogue. However, they set the doctrine of Saturday in a markedly prophetic and eschatological framework. A consequence of this was the view that observing Sunday is an attack on Divine truth conducted by the papacy in an effort to abolish Saturday observance throughout the world and replace it with Sunday. ${ }^{13}$

This interpretation fit the aroused atmosphere of the time. The Adventists had a fairly fresh experience from 1843-1844, when as members of the Millerite movement they were being excommunicated by their churches, who on their view acted more in accordance with their creeds than with the Bible. ${ }^{14}$ They linked this experience with their interpretation of Saturday

retrieved January 7, 2014.

7 The reluctance to revise the principles of the Millerite attitude to the Bible is witnesses e.g. by the statement: "To deny that the days ended at that time was to involve the whole question in confusion, and to renounce positions which had been established by unmistakable fulfillments of prophecy." Ellen G. WHITE, The Great Controversy, Mountain View: Pacific Press Publishing Association, 1950, p. 410.

8 The basic Adventist understanding of the Bible remained literal, as it had been with Miller: "I found that, by a comparison of Scripture with history, all the prophecies, as far as they had been fulfilled literally; that all the various figure, metaphors, parables, similitudes, etc. of the Bible were either explained in their immediate connection, or the terms in which they were expressed were defined in other portions of the word; and, when thus explained, are to be literally understood in accordance with such explanation." James WHITE, Sketches of the Christian Life and Public Labors of William Miller, Battle Creek: Steam Press, 1875, p. 48.

9 The historicist interpretation of prophecies assumes that the apocalyptic biblical visions of Scripture form a consequent historical line coded in symbolic expressions - a history of the conflict of God's people and the powers of evil. This line runs from the time when the biblical author was writing the text to the Second Coming of Christ. Around 1850 this approach was broadly taken both by postmillenialists, such as Jonathan Edwars, and premillenialists, such as William Miller. Cf. Douglas MORGAN, Adventism, Apocalyptic, and the Cause of Liberty, Church History 2/1994, pp. 236-237. For contemporary view of the historicist interpretation in Adventism see e.g. Reimar VETNE, A Definition and Short History of Historism as a Method for Interpreting Daniel and Revelation, Journal of the Adventist Theological Society, 2/2003, pp. 1-14. 10 Cf. e.g. Adventisté sedmého dne věři - Výklad základních věroučných článkư, Praha: Advent-Orion, 1999, pp. 198-199 or ibid., pp. 306-310.

11 "It has been shown that the United States is the power represented by the beast with lamblike horns, and this prophecy will be fulfilled when the United States shall enforce Sunday observance, which Rome claims as the special acknowledgment of her supremacy." Ellen G. WHITE, The Great Controversy, pp. 578.

12 Douglas MORGAN, Adventism, Apocalyptic, and the Cause of Liberty, p. 238.

13 Cf. Geroge KNIGHT, Adventismus v proměnách času, Praha: Advent-Orion, 2003, pp. 35-36.

14 "The Millerite movement began in 1840 as supra-confessional and in 1844 ended up as a separatist group." J. R. PÖHLER, Der adventistisch/röm.-katholische Dialog. Erste Schritte: Adventisten und Katholiken im Gespräch, Ausgabe, 2007, p. 143. As a result its members 


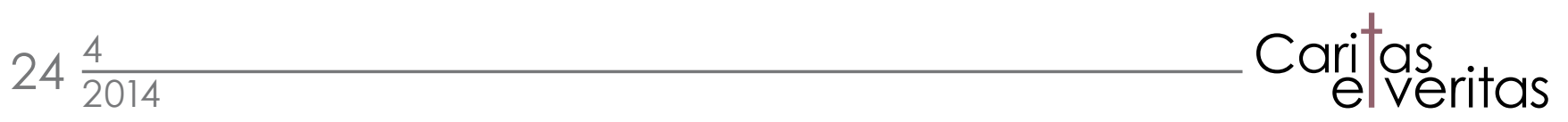

and prophecies and found support for their theory in the proposals for legislation to enforce Sunday observance appearing in America at the time. ${ }^{15}$ They considered the Sunday, as a false Saturday introduced by the papacy, to be a sign of cession from true Protestantism and acceptance of the non-Biblical papal teaching. The unity of Protestants and Catholics thus manifests itself precisely by supporting the observance of Sunday. ${ }^{16}$

As we shall show below, all these eschatological emphases are still operative in official Adventist theology in virtually unchanged form at present and without taking them into account contemporary Adventism cannot be correctly understood.

\section{Adventist relationship to 19 th century American society}

Thus the first Adventists' strained eschatological expectations gave rise to a cautious and distrustful attitude to state power among them. This was due not only to the "prophetic" orientation, but also to the pacifist view they had received both from William Miller and from the Christian Connection. ${ }^{17}$ The Seventh-day Adventist Church officially came to be in 1863, i.e., in the midst of the American Civil War. Its pacifist stance made its situation difficult. Although the Adventists rejected slavery ${ }^{18}$ as inconsistent with Republican principles (it supported their view of the USA as the beast) ${ }^{19}$ they refused to take active military part in the fight for its abolition. This also had to do with observing Saturday: "If they resisted military service out of faithfulness to Scripture, they risked accusations of disloyalty, a severe government crackdown on their movement just as it was getting off the ground, and indirectly abetting the slave system they so fiercely opposed. Joining freely in armed combat, though, would make a mockery of their claim to be a remnant faithful to the commandments of God and faith of Jesus." 20

Of course the radical, clear, direct and polarizing division of the world into a fight of good with evil (Saturday with Sunday) resulted in fear of oppression from the state. This gave rise to tension, which was further underscored by some cases of Adventists punished for working on Sunday. ${ }^{21}$ Since the Adventists further saw themselves as called to missionary effort, they sought to prepare ground for it by actively defending religious freedom, which they saw as threatened by the attack on the Saturday. "In 1883 they launched a publication devoted to advocacy of religious liberty and targeted to reach individuals most influential in shaping public

were negatively perceived by their churches and excommunicated.

15 Cf. George KNIGHT, Adventismus v proměnách času, p. 76.

16 See Douglas MORGAN, Adventism, Apocalyptic, and the Cause of Liberty, p. 238.

17 Cf. Peter BROCK, Freedom from Violence: Sectarian Nonresistance from the Middle Ages to the Great War, Toronto: University of Toronto Press, 1999, p. 231.

18 For example the first chairman of the General Conference of Seventh-day Adventist Church John Byington was one of those who actively participated in the so-called "underground railway" - a network used by runaway slaves from the American South on their way to freedom. See e.g. Michael PEARSON, Millennial Dreams and Moral Dilemmas: Seventh-Day Adventism and Contemporary Ethics, Cambridge: Cambridge University Press, 2008, p. 20.

19 See Douglas MORGAN, Adventism, Apocalyptic, and the Cause of Liberty, p. 238.

20 (C) Douglas MORGAN, Following the Prince of Peace in a Time of War: How the Adventist Pioneers Dealt with Issues of War, Peace, and Military Service, Adventist Review, 2007 (on-line), at http://archives.adventistreview.org/issue.php?issue=2007-1516\&page=13, retrieved January 7, 2014.

21 "The 1880s represent a turning point in the history of the Adventist Church. The entire second half of the 19th century in the USA was marked by the effort of organizations, such as e.g. the National Reform Association, to maintain the Christian character of America, among other things by protecting the sacredness of Sunday. At the beginning of the 1880s there began to appear conflicts in the USA between state power and the Adventists, which the Adventists perceived as fulfillment of the prophecies concerning the persecution of faithful observers of Saturday. However, their problems did not arise from a ban to observe Saturday as a holy day and to gather for worship, but from the fact that they worked on Sundays. The Adventists therefore viewed the 1888 proposal of Senator H. W. Blair to nationwide Sunday observance legislation in negative light. All this forced them to increasingly stress the eternal validity of the Decalogue, especially the commandment concerning observing Saturday." Bedřich JETELINA, Adventisté sedmého dne mezi modernou a postmodernou, dissertation thesis, České Budějovice: Teologická fakulta Jihočeské univerzity, 2013, p. 123. 
policy. Originally titled the Sabbath Sentinel, it was renamed the American Sentinel in 1886 and then Liberty in 1906." 22 In 1893 the Adventists founded an organization called International Religious Liberty Association (IRLA), which aims to "disseminate the principles of religious liberty throughout the world; defend and safeguard the civil right of all people to worship or not to worship, to adopt a religion or belief of their choice." 23 The Adventists today still speak of this organization as non-sectarian, ${ }^{24}$ which they see as supported by the fact that despite having the fear of suppressing the right to observe Saturday as its point of departure, it has been consistent in its defense of religious freedom and has advocated even the rights of "Catholics, Jews, and infidels". ${ }^{25}$

But the first Adventists also wished to engage in social issues and, besides abolition of slavery and pacifism, supported the then wide-spread abstinence movements and movements supporting temperance. E.g. S. M. I. Henry, the coordinator of the radical social movement "Women's Christian Temperance Union" became an Adventist at the high point of her career, "because she saw in the Adventist Church the social action values in which she believed". ${ }^{26}$ One of the leading activists of the temperance movement was also one of the church's founders Joseph Smith. ${ }^{27}$ Warning against the danger of abusing alcohol and tobacco, which was in line with the mainstream opinion of other Protestant churches in the USA, obtained a specific tint among the Adventists due to the visions of Ellen White. ${ }^{28}$

Other outstanding social issues pursued by many founders of Adventism were support of absolute equality of men and women, including spiritual ministry, and emphasis on the development of medical care and schooling. ${ }^{29}$ Finally, one of the basic social issues of the first Adventists was care of the poor. ${ }^{30}$

Thus with respect to social issues the Adventists in no way deviated from the concerns of other American conservative Christians and members of religiously motivated reform movements of the time. The Adventist specificity only manifested itself in fears of persecution from the state concerning the observance of Saturday and their exalted eschatological expectations led them to try to project them onto their present situation.

\section{Some paradoxes of the Adventist approach to human rights and social issues in the 20th century}

The sharp, black-and-white view based on anti-Catholicism and fear of persecution for observ-

22 Douglas MORGAN, Adventism, Apocalyptic, and the Cause of Liberty, p. 241.

23 () International Religious Liberty Association (IRLA) (on-line), at http://www.irla.org/mission-purpose-and-principles, retrieved January 7, 2014.

24 In Adventists' own view: "The interest of Adventists in religious freedom probably has no equivalent in the Christian world. It has to do with their eschatological vision, their reading of history, and, of course, their theology; but also with their experience as a religious minority facing challenges as they try to live their beliefs and, among them, resting on the Saturday Sabbath. It gives to Adventists openness to those who are persecuted and discriminated against." (c) Seventh-day Adventist Church - Public Affairs and Religious Liberty (on-line), at http://150.adventist.org/history/public-affairs-and-religious-liberty.html, retrieved January 7, 2014.

25 Douglas MORGAN, Adventism, Apocalyptic, and the Cause of Liberty, p. 243.

26 Social Action Now: A Challenge to the Seventh-day Adventist Church, in: Symposium on Mission and Social Action: The Role of Social Ministry in the Seventh-day Adventist Church, ed. John WILCOX, Silver Springs: ADRA, 1997, p. 13.

27 Ibid.

28 Ellen White was convinced that the health message and the message of temperance, the so-called "health reform", were "the right hand of the gospel". See e.g. Ellen G. WHITE, An Earnest Plea, Review and Herald, January 7, 1902, p. 12. For more detail on the topic cf. Ronald L. NUMBERS, Prophetess of Health? A study of Ellen G. White, Grand Rapids: William B. Eermans Publishing Company, 2008.

29 Although schooling and health care belong in the sphere of church social work, it is such a specific and extensive area that it would require separate treatment.

30 See Social Action Now: A Challenge to the Seventh-day Adventist Church, pp. 13-14. 


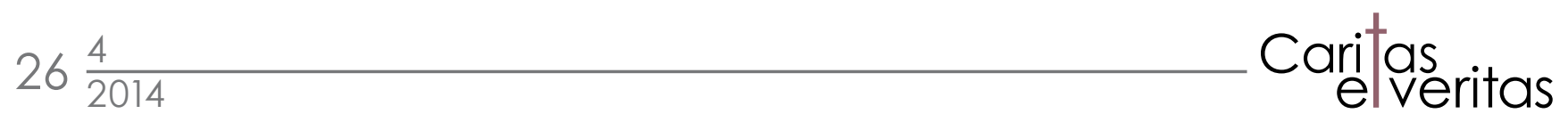

ing Saturday corresponded to the Adventists' perception of American society in the second half of 19th century. But in the 20th century, when the Adventist church spread throughout the world, it proved incapable of sufficiently grasping the complexity of the world.

At the beginning of the 20th century, American Protestantism came to be dominated by Christian fundamentalism, whose emphases also affected Adventism. Along with the fundamentalists the Adventists set themselves (as part of fighting "liberalism") against the concept of "social gospel", introduced by the Baptist preacher Walter Rauschenbusch, who concluded that sin comprises a social element. ${ }^{31}$ The alternative they set against the "social gospel" was evangelization. ${ }^{32}$

As Adventist sources admit, this attitude was influenced by anti-Catholicism, among other factors. ${ }^{33}$ In 1920s America was flooded by a wave of poor immigrants from Europe, mostly Catholics, who were not received well by the Protestant inhabitants. ${ }^{34}$ The Adventist anti-Catholic interpretation of prophecies was consonant with that and was apparently one of the factors that led American Adventists to lose interest in typically social issues and engage themselves only with education, healthcare and evangelization. ${ }^{35}$

But by that time Adventism had already spread in Europe, where the religious and philosophical situation was different from the one in the USA and social commitment and care of the poor played a more important part. In central Europe it was encouraged by the German Adventist Hulda Jost, who maintained the philanthropic society Adventwohlfahrtswerk in Germany since 1926. ${ }^{36}$ This work was transferred to the then Czechoslovakia in 1929 when Tabita circles, focusing on helping the poor, started operating within individual Adventist congregations. Besides Tabita, the Society for Care of the Health was founded and Tabita later became subsumed under it. At the same time health-preventive emphases became dominant in its activity. This also seems consonant with the trend which had appeared within Adventism in the USA, where health care came to be perceived as more important than social care.

In the 20th century Adventism also had to come to terms with church life under totalitarian regimes. However, totalitarian regimes did not meet the basic criteria of the Adventist prophetic interpretation characterizing God's enemy - it was evident that neither Nazism nor communism was dominated by Catholicism.

The false view of Catholicism as the main enemy was thus apparently one of the reasons why in Nazi Germany "Adventists expressed enthusiastic praise for Hitler and the National Socialists, and most conscripts bore arms willingly even though they had been accorded the right to opt for orderly or medical duties. Through such actions the Adventist Church there successfully reduced tension with the regime, so that it survived untouched in spite of the similarity of several of its beliefs and practices to Judaism." ${ }^{37}$

\footnotetext{
31 See Samuel G. LONDON, Seventh-day Adventists and the Civil Rights Movement, p. 71.

32 See George M. MARDSEN, Fundamentalism and American Culture, Oxford: Oxford University Press, 2006, pp. 90-93.

33 See Social Action Now: A Challenge to the Seventh-day Adventist Church, p. 16.

34 See Karen ARMSTRONG, The Battle for God, New York: The Random House Publishing Group, 2001, pp. 145-146.

35 See ibid., p. 13.

36 See Jiří PIŠKULA, Dějiny církve adventistů sedmého dne v Čechách na Moravě a ve Slezsku, Praha: Advent-Orion, 2009, p. 68.

37 Ronald LAWSON, Sect-State Relations: Accounting for the Differing Trajectories of Seventh-day Adventists and Jehovah's Witnesses, Sociology of Religion, 4/1995, p. 358. For the ambiguity of the Adventist attitude during World War II in the Czech lands as well as Slovakia see Jiří PIŠKUULA, Déjiny Církve adventistů sedmého dne v Čechách, na Moravě a ve Slezsku, Praha: Advent-Orion, 2009, pp. 73-82.
} 
This also became manifest in the attitude to communism. In the Czech Republic the Adventist church was prohibited from 1952 till 1956. The prohibition occurred despite the church's effort to maximally meet the regime's expectations. Some members even saw no problem in Communist Party membership. ${ }^{38}$ The crucial confrontation had to do with observance of Saturday, ${ }^{39}$ which confirms its extraordinary status in Adventist perception of the world. At the same time it evinces a misunderstanding of the anti-Catholic, anti-American Adventist stance, willing to compromise with the communist power, as manifested by Communist counter-church ideologists. And these, even more then the accommodating pro-Communist Adventist attitudes, sketch out how deeply fear of the Catholic Church was rooted in Adventism.

This is illustrated by tragic statements at a time when large numbers of Adventists conscripted to basic military service were undergoing inhumane treatment in communist concentration camps. Despite that the lay preacher Konečný from Boskovice stated at a time when Adventist church property was being confiscated by state power (!): "If the Catholics were engaging in this operation, it would be worse, we have no fear of the organs of popular administration, who deal with us decently." ${ }^{40}$ Perhaps even more telling is in this sense the statement of preacher T. J. Zikmund, who wrote in an illegal (!) bulletin to church members: "We know that if the enemies of peace succeeded in starting a third world war and winning it, yet greater difficulties would arise for us Adventists. Enemy elements, the American-Vatican imperialism would introduce new inquisitions against us, and not only against us but against everything that does not smell of imperialist Vatican perfume. Study the 13th and 17th chapter of the Revelation thoroughly." 41

In the "popular-democratic" Poland a much more pragmatic stance to the Seventh-day Adventist Church was taken than in the Czech Republic and the church's cooperation with the state took the form of open collaboration with the regime. Polish state leadership won the Adventists over to their side and these, faithful to their prophetic orientation, "were willing to attack its prime enemy, the Catholic Church. For example, they published one such issue of their magazine to coincide with Pope John Paul 1I's first visit home. In return for their assistance, although their membership stood at only 4,700 members in a total population of 38 million, they were allowed to publish so freely that during the last seven years of the Communist regime the amount of Ellen White's material published was exceeded only by the Bible and the works of Lenin. They were also allowed the privileges of selling their material freely on the streets and in government book kiosks, and of securing public halls for evangelism." 42

But this Adventist anti-Catholicism did not make Adventists an anti-communist, leftist church in the second half of the 20th century. At the same time as they were cooperating with the regime in Poland, in Chile during the reign of general Pinochet they "were known as friends of the president, providing him with legitimation from a religious source when he was under attack from the Catholic Cardinal for torture and disappearances. In return they received accreditation for their college. In South Korea, rather than protesting against the military regimes of Presidents Park and Chun, Adventists were cooperative and loyal, appreciating the stability and social control imposed by the regimes, and their campus remained extraordinarily quiet." ${ }^{43}$

\footnotetext{
38 Since 1950 even the leading representative of the church and later chairman Tobiás J. Zigmund was a Party member. See ibid., p. 106.

39 E.g. ibid., pp. 111 and 113.

40 Ibid., p. 161.

41 Ibid. (We do not know to what extent Zikmund expected that the illegal bulletin would fall in the hands of the state police and whether perhaps writing it in this way was not motivated by this intention. Even in such case its tone is consonant with Adventist points of departure.) 42 Ronald LAWSON, Sect-State Relations: Accounting for the Differing Trajectories of Seventh-day Adventists and Jehovah's Witnesses, p. 361. 43 Ibid., p. 360.
} 
However, this cannot be simply labelled as opportunism and an effort to make friends with any governing power at all cost. This is opposed by facts of sacrifices that ordinary members as well as some church representatives were willing to bring for their faith. ${ }^{44}$ An explanation is again offered by Adventist eschatology, according to which only the one "biblically" determined is a real enemy, even when he does not behave like one. But one who manifests all marks of brutally suppressing human rights and freedoms, and even attacks Adventists, is met obligingly because the "prophecies" do not speak of him thus.

While the Adventist attitude to social issues in the 20th century can be seen as compatible with Christian fundamentalism, the accommodating attitude to communism does not accord with American fundamentalist Christians. ${ }^{45}$ An explanation that suggests itself is that the question came to be dominated by observance of Saturday, which became a determinative ethical principle, to which the Adventists subordinated the whole sphere of understanding human rights.

\section{Adventists and the challenges of the 21 th century}

Since the fall of the Iron Curtain and the events of September 11, 2001, the world social climate has changed and the polarized tension "East - West" of the Cold War has disappeared. The issue of human rights and religious freedom has also attained new dimensions, which are becoming ever more remote from the original ideas of the founders of the Seventh-day Adventist Church in the 19th century. ${ }^{46}$ Relationship to communist ideology and the atheism deriving from it has ceased to be an issue in the worldwide discussion of human rights, while issues such as the rights of sexual minorities or gender questions a being emphasized (especially by the media). The issue of religious freedom is still crucial, but not, as Adventists had presumed, in the relationship Protestantism - Catholicism; the questions currently being discussed are mostly related to Islam. ${ }^{47}$

The challenges the Seventh-day Adventist Church must face in the 21th century are very different in the developing world, where it is experiencing a great boom, and in the Western world, where it merely holds the status quo or even suffers a decrease in the number of members. ${ }^{48}$ The statistics of numeric growth allows one to infer that, unlike in the West, in the developing world the Adventist articles of faith from the 19th century raise interest. Although (and perhaps precisely because) voices have appeared in the USA and especially in Europe saying that it is necessary to reflect the changed situation of the Western world, ${ }^{49}$ Adventism in the

\footnotetext{
44 See e.g. Pavel JADLOVSKÝ, Perzekuovaní adventisté sedmého dne v komunistickém Československu, diplomová práce, České Budějovice: Teologická fakulta Jihočeské univerzity, 2009.

45 See e.g. Karen ARMSTRONG, The Battle for God, p. 216 or George M. MARDSEN, Fundamentalism and American Culture, pp. $209-211$.

46 Even within Adventism there has for twenty years existed a group of theologians who acknowledge that "19th century Adventism was perceived as exclusive, hypercritical, and elitist, and that many members harbored a persecution complex. To live one's life expecting mortal danger from both friend and foe is not to truly live." Madelynn JONES-HALDEMAN, Progressive Adventism: Dragging the Church Forward, Adventist Today, 1/1994, pp. 10.

47 Cf. e.g. Jan SVOBODA, Islám versus západ: Možnosti transformace civilizačního konfliktu v interkulturní dialog, Auspicia, 2010, pp. 129-132.

48 Of the total 1139000 Adventists baptized worldwide in 2011 19.61\% come from South America, 18.67\% from southern Africa and the Indian Ocean area, $18.44 \%$ from eastern and central Africa and $16.94 \%$ from Central America. 3.47\% came from the USA and $0.81 \%$ from Central and Western Europe. See @ 2013 Annual Statistical Report: 149th Report of the General Conference of Seventh-day Adventists for Year Ending December 31, 2011, p. 5 (on-line), at http://docs.adventistarchives.org/docs/ASR/ASR2013.pdf?q=docs/ASR/ASR2013.pdf, retrieved January 7, 2014.

49 "Responsible contextualization" of Adventist doctrine is discussed e.g. by the German Adventist theologian Rolf J. Pöhler. See Rolf J. PÖHLER, Does Adventist Theology Have, Or Need, a Unifying Center, in: Christ, Salvation and the Eschaton, ed. Daniel HEINZ - Jiri MOSKALA - Peter M. van BEMMELEN, Berrien Springs: Old Testament Department, Seventh Day Adventist Theological Seminary, Andrews University, 2009 , p. 31.
} 
21th century still insists on its original methodological presuppositions, including interpreting history as, metaphorically speaking, a "Saturday vs. Sunday strife". ${ }^{50}$

But the Roman Catholic Church, as the results of 2nd Vatican Council are becoming ever more manifest in its practice, does not correspond to the characteristic of the "beast", as it is labelled by Adventism. ${ }^{51}$ It is becoming more and more difficult to interpret the moves of the post-Council popes towards religious tolerance, the strong social commitment of the Catholic Church, the effort to solve problem within the Curia, or the non-formal unpretentiousness of Pope Francis as sophisticated effort to gain control of the world by cunning. ${ }^{52}$ Also, Adventist effort in striving for religious freedom, as well as effort at official discussion and elucidation of positions with representatives of other churches, including the Roman Catholic Church, ${ }^{53}$ has brought fruit in the form of good personal relationships and growing understanding of the Adventist specificity on the part of other Christians, including Saturday observance. The traditional Adventist picturing of these churches as enemies is thus becoming ever more complicated and humanly unacceptable. ${ }^{54}$

A further problem opposing the traditional Adventist interpretation of prophecise is the weakening role of the USA in the world and the rising power of China and the Islamic world - of which Adventist interpretations of prophecies do not speak, as they did not speak of communism or Nazism in the past. ${ }^{55}$ And both Catholicism ${ }^{56}$ and the USA government ${ }^{57}$ have paradoxically in some cases become allies of Adventism in defending human rights and Adventist representatives are at the very least not opposing the cooperation.

50 "In passages such as Daniel 7:20-25 (the little horn) and Revelation 13:1-7 (the beast from the sea), this same power operates after the fall of the pagan Roman Empire, combining both religious and secular authority to persecute the saints of God. The only power in history that fits all the specifications of these prophecies is the papacy. Many interpreters from the Middle Ages, and even to this day, have designated this institution as the antichrist... But at the close of history, just before the Second Coming, there will be an even more world wide, open defiance of God and His laws. The continuity of powers, both in this passage and elsewhere (Daniel 7 and Revelation 13), indicates that the papacy will play a major role at the end of time, as well". Jon PAULIEN, 1 and 2 Thessalonians, The Adult Sabbath School Bible Study Guide, Silver Spring: Sabbath School Personal Ministries, 2012, p. 100. The quotation comes from a periodical for the so-called Sabbath school, published by the Seventh-day Adventist Church as Bible study tool. Their text is identical worldwide, since a purpose of the Sabbath school is to maintain unity of church doctrine.

51 For example the claim that the Catholic Church follows its goals "even at the ruin of princes and peoples" would hardly stand against the text of the Vatican Council document Gaudium et Spes. See Ellen G. WHITE, The Great Controversy, p. 580.

52 "Marvelous in her shrewdness and cunning is the Roman Church. She can read what is to be. She bides her time, seeing that the Protestant churches are paying her homage in their acceptance of the false sabbath and that they are preparing to enforce it by the very means which she herself employed in bygone days." Ellen G. WHITE, The Great Controversy, p. 580. It is worth mentioning that the Adventist interpretation of apocalyptic prophecies concerning the Catholic Church, of which it speaks as of a non-reformable institution, is inconsistent also with respect to the fact that Adventists consider themselves Arminian and therefore reject predestination, which does not hold for Catholicism in prophecies. 53 In 1965-2011 Seventh-day Adventists held official dialogues with representatives of twelve churches and religious alliances (such as e.g. the World Evangelical Alliance or the World Council of Churches) and even with representatives of the Bishops' Conference of Poland. These dialogues concerned both dogmatic questions and social and missiological issues. See Stefan HÖSCHELE, Eschatology and Theological Dialogue: Insights from Adventist Interchurch Conversations, One in Christ 1/2013, pp. 38-39.

54 For example, Seventh-day Adventists have together with churches gathered in the Ecumenical Council of Churches of the Czech Republic and with the Czech Bishops' Conference taken part in negotiations concerning the restitution of church property and together with the other churches signed the contract with the Czech Republic. At local level they commonly take part in ecumenical prayer events, charity projects etc. 55 The way Adventists speak critically of the Inquisition and consider Catholicism to be the main violator of human rights in the world does not reflect historical reality. The horrors of the Shoah and of communist concentration camps are many times greater and have had such farreaching historical impact that it seems strange that the "historicist" interpretation of prophecies should not mention them at all.

56 E.g. in the case of the Supreme Court decree from January 11, 2012, concerning the fact that no one can claim the right to employment in a church institution on the grounds of anti-discrimination laws. This verdict was welcomed by both Adventists and representatives of the Catholic Church as important for religious freedom. See @ On Religious Liberty, Adventists Join Hands With Catholics, Spectrum (on-line), at http://spectrummagazine.org/node/3744, retrieved January 7, 2014.

57 E.g. in 2000 there appeared the TV documentary A vital force for freedom produced by the Department of Religious Liberty of the North American Division of Seventh-day Adventist Church (the covering organizational unit of the church in the USA), in which the Adventist attitude to religious freedom is praised by the then President of the USA George W. Bush or the then Senator John Kerry. In 2005 Adventists organized a conference at which their activity was publicly appreciated by the then Senator Hillary Clinton. Cf. @ Liberty (on-line), at http:// www.libertymagazine.org/article/honoring-liberty, retrieved January 7, 2014. 
In social work issues there is manifest effort to overcome the fundamentalist legacy of the 1920s. The humanitarian organization ADRA provides not only humanitarian relief, but also development aid, and strives not to link it to the church's missionary work. Clearly, these two aspects cannot always be separated and the church's distance is not always desirable, since, at least in countries like the Czech Republic, ADRA is one of the most effective Adventist advertising tools.

As the Adventist Church does not have a wholly clear stance to social and political commitment, so it is experiencing difficulty in finding an attitude to the issue of the rights of sexual minorities ${ }^{58}$ and recently especially to the equality of women. This is an especially sensitive issue due to the debate concerning ordination of Adventist women as full-fledged clergy. Since Adventists do not conceive ordained ministry in sacramental terms and since they have always defended equal rights of men and women, there should be nothing to prevent women from serving the church as ordained clergy. But due to the pressure of the church in the developing world and of fundamentalist members and clergy the discussion is lively and even settling it administratively would not bring the debate to an end. ${ }^{59}$

So far, Adventism has faced all these challenges in a pragmatic way. Where the emphases of the 19th century are effective (the Third World), it continues to stress and openly proclaim them. ${ }^{60}$ Where they would not be accepted and understood (the West), it does not publically pronounce them, neither, however, does it deny them. At world level the Public Affairs and Religious Liberty Department of the General Conference of the Seventh-day Adventist Church ${ }^{61}$ closely cooperates with the organization IRLA ${ }^{62}$ and surveys observation of religious freedom throughout the world, with emphasis on the freedom to observe Saturday. ${ }^{63}$ The church itself perceives it as an important contribution to the issue of freedom of conscience. It nonetheless concludes that "Surprisingly, the largest contribution of the IRLA is not the advancement of Sabbatarian issues or Biblical ideals, but rather a steady position of upholding all religious liberties and the separation of church and state, regardless of whether the case involves issues central to the Adventist faith or even opposes Adventism's core beliefs." 64

\section{Conclusion}

Although Adventist periodicals reflecting the origins of the church give the impression that

58 Cf. () Seventh-Day Adventist Position Statement on Homosexuality, Statements, guidelines and other Documents, Silver Springs: Review and Herald Publishing Association, 2010, p. 61; or the conclusions of church theological conference devoted to sexual minorities: (C) Preserve Identity of Church, but Minister to Gay and Lesbian Community, Panelist at Adventist Sexuality Summit Say (on-line), at http://news. adventist.org/all-news/news/go/2014-03-19/preserve-identity-of-church-but-minister-to-gay-and-lesbian-community-panelists-atadventist-sexua/12/, retrieved April 16, 2014.

59 Cf. e.g. @ In Six To One Vote, NAD Affirms Women's Ordination, Spectrum (on-line), at http://spectrummagazine.org/node/5620, retrieved January 7, 2014.

60 An example of this may be the church-supported organization Share Him, which specializes in organizing evangelizing trips of preachers from the USA and Europe to Third World countries. Within the two-week campaigns they must observe both the order and content of the topics they present. The main content of the campaign is the classical Adventist understanding of eschatology and interpreting prophecies. Cf. ( ) Share Him (on-line), at http://sharehim.org/php/docs/Sermon_Topics.pdf, retrieved January 7, 2014.

61 See $@$ Seventh-Day Adventist Church, Department of Public Affairs and Religious Liberty (on-line), at http://www.adventistliberty.org/, retrieved January 7, 2014.

62 Besides IRLA the Adventist are also active in the International Association for the Defense of Religious Liberty (IADLR). This was founded in 1946 by Jean Nussbaum. Its honorary presidents have been Eleanor Roosevelt or Albert Schweitzer, but its secretary is always an Adventist preacher and its headquarters are in the offices of the European Adventist Leadership in Bern. For more see e.g. (C) Seventh-Day Adventist Church - History (on-line), at http://150.adventist.org/history/public-affairs-and-religious-liberty.html, retrieved January 7, 2014.

63 E.g. in 2006 this department dealt with almost a thousand cases when people all around the world experienced problems due to refusing to work on Saturday. See () Duane McBRIDE and Jacquelyn GIEM, The Christian Church and Society: Some Functions, Dysfunctions, Conflict, and Interactions in 3rd Symposium on the Bible and Adventist Scholarship Akumal, Riviera Maya, Estado Quintana Roo, Mexico, March 19-25, 2006, p. 18 (on-line), at http://circle.adventist.org/files/CD2008/CD1/fae/essays/34B_McBride_D.pdf, retrieved January 7, 2014. 64 Ibid. 
Adventism played an almost crucial role in the USA in both social issues and human rights issues and came ahead of its time in a whole number of emphases, this is not the case. As examples one can cite the issues of temperance and pacifism, as well as e.g. the racial issue. The fact that Adventist fought against slavery does not mean that they fully accepted equal rights of black and white-colored humans. At the end of the 19th century Ellen White, the key figure of Adventism, on the one hand supported mission among the blacks and acknowledged their equality, but on the other hand her attitudes fully corresponded with the ideas of racial segregation prevalent at the time. ${ }^{65}$

Nor were the Adventist emphases on human sights and social issues in later periods in any way revolutionary and despite their points of departure, which may appear non-standard with respect to mainstream American Protestant opinion (the relationship of Saturday to USA and Catholicism), Adventists mostly copied the attitudes of conservative American Christians. A difference can only be found in relationship to totalitarian regimes, where the ethical dimension of observing Saturday and anti-Catholicism led to dubious compromises. In the 21th century Adventists still declare their specific theological points of departure. However, within the general non-Adventist discussion in the field of religion, human rights and social work the issue of anti-Catholicism, especially in relation to observing Saturday, appears marginal. Other issues are dominant, which are also widely discussed in contemporary Adventism - especially the relationship of Christianity and Islam, the rights of sexual minorities or gender and family issues. The original Adventist theological points of departure are only minimally reflected in the concrete practical Adventist activities in the field of human rights and social work. This means that rather than by open anti-Catholicism and sharp eschatological emphases these activities are justified by divine love, human dignity, freedom of conscience, religious tolerance, education, peaceful cohabitation of nations or economic development of Third World countries. ${ }^{66}$

We can conclude that despite its theological points of departure Adventism has played a mostly positive part in protecting human rights and especially the right to religious freedom. Its commitment to social work, health care, education or humanitarian relief and development aid has also played a positive part. In racial issues, women's rights, workers' rights or debates concerning sexual minorities it mostly takes conformist stances in line with the conservative American Christian stream. This suggests that fundamentalist Christian anchoring is prevalent in Adventism. But excesses, such as relationships to totalitarian regimes motivated by Adventist specificities, at the same time pose a warning that over-simplification and ideological blindness are still present in Adventism. However, the abandonment of social emphases by Christian fundamentalists in the 1920s motivated by anti-Catholicism shows that the danger is by far not unique to Adventists.

\section{Seventh-day Adventists, Human Rights and Social Work}

Abstract The paper deals with the motivation that led the Seventh-day Adventist Church to engage in human rights and social work and reflects some of the practical implications of this motivation. It shows that the Adventists of the 19th century took over from the Millerite movement the so called historicist interpretation of biblical prophecies. As a result, the Adventists see history as a battle between true and

65 See e.g. R. Clifford JONES, James K. Humprey and the Sabbath-Day Adventists, Jackson: University Press of Mississippi, 2006, pp. 95-100. 66 Cf. e.g. CADRA International - Our Mission (on-line), at http://www.adra.org/site/PageNavigator/about_us/our_mission.html, retrieved April 16, 2014 or @ Freedom to Believe (on-line), at http:/ / www.adventist.org/service/religious-liberty, retrieved April 16, 2014 etc. 
false religion. True religion is characterized by observing the Sabbath as day of worship, false religion by observing Sunday. Observing Sunday will in the future be enforced by force, and Catholicism and the USA will cooperate to achieve this goal. Defending human rights, in particular the right to religious freedom, is intended to confront this effort. Adventists have also perceived their social commitment from this perspective. Although Adventist practical work in the field of human rights and social work generally follows the attitudes of conservative American Protestants, the text provides examples of some specific problematic attitudes, which have in the past led to ethically controversial acts.

Key words Seventh-day Adventists, Saturday, Sunday, Catholicism, human rights, social work, USA, abstinence, religious freedom 